\title{
The Implementation of State Policy of Power Cleaning in the Conditions of Political Transformation: Experience of Ukraine and Countries of Central and Eastern Europe
}

\author{
Valentyna Goshovska ${ }^{1}$, Volodymyr Goshovskyi ${ }^{2}$, Liudmyla Dubchak ${ }^{3}$,
}

\begin{abstract}
The article analyzes the problems of realization of the state policy of power cleaning in the countries of Central-Eastern Europe (Poland, Czech Republic, Hungary, Baltic countries), and in particular in Ukraine. It has been found that in various countries this step in the public administration was taken since the fall of the communist regime. However, everywhere it was carried out by its own rules.

The attention is drawn to the fact that the power cleaning through lustration should be ensured in the light of a wide range of threats that pertain to the human rights sphere and the principle of the presumption of innocence. This was relevant for every state that embarked on the path of transformational change to the implementation of a state policy of power cleaning. None of the countries that have taken such a political step in the public administration system went this route easily (there were both claims to the laws with subsequent legislative initiatives to amend them, and suits to courts of various instances to restore human and citizen's rights and freedoms). However, there were also positive consequences, which resulted in the cleaning of the authorities of the respective countries from the influences of interested pro-communist political forces, which hindered democratic transformations in the states.

Regarding the characteristics of the state policy of power cleaning by lustration in Ukraine, which began only in 2014, we drew attention to the fact that it had a different meaning: it was not aimed at combating the communist past, but at overthrowing the current political regime of "Yanukovych times". There were some problems, which reflected the emergence of relevant issues in such events of the public administration system, which caused criticism from a number of external international human rights organizations (for example, the Venice Commission), and led to massive claims to courts of various instances aimed to restore of claimants' rights.

Also the article draws attention to the fact that lustration, as a mechanism of power cleaning, is an appropriate political step on the way to democratization of society and overcoming the negative consequences of the activity of undemocratic political regimes. However, its implementation requires a prudent approach to defining the principles of legal regulation, the establishment of appropriate institutions to ensure the implementation of lustration and guaranteeing the protection of human and citizen's rights and freedoms from political persecution.
\end{abstract}

Keywords: sustainable development, public policy, cleaning of power, lustration, protection of buman and citizen's rights and freedoms. 


\section{Introduction}

In the conditions of long unstable political development of Ukraine since the country independence, with transformational changes in the public administration system as a whole, as well as in certain branches and spheres of public life, the problem of rebooting power and providing high quality professional staff of the senior public administration corps repeatedly appeared. After all, a state that has been permanently in the last 30 years in condition of deep public turmoil related to discrediting public administration factors, including unqualified governance, high levels of corruption, lack of transparency in government, etc., needs changes. Therefore, the urgency of personnel changes was on the agenda of the next state changes, prompted by civil protests in the early 90's of the twentieth century, in 2004 - 2005 and last in 2014. Each of these stages of public administration development in the implementation of state policy of power cleaning was not fully implemented

The turning point in 2014 was the closest to the implementation of the new state policy of power cleaning. It was this stage in the development of Ukraine that prompted the outbursts of discontent with the state policy of the senior management of the state, which resulted in mass civil protests and ended with the events of the Revolution of Dignity and the escape of then president V.Yanukovych.

The chosen mechanism for the power cleaning was lustration.

The term "lustration" has a long-standing origin. It can be found even in Greco-Roman mythology, as well as in somewhat later times - in the Middle Ages, etc. However, this term has become of modern significance since the 1990th - at a time of political transformation that took place in the countries of Central and Eastern Europe during the "velvet revolutions".

To date, there is no single general definition of the "lustration" term. This is due to the wide range of lustration practices that have taken place in the implementation of public policy in different countries.

In the scientific literature there are several approaches to the definition of "lustration". According to a number of scientists, lustration is understood as a certain check or screening of candidates for top management positions according to their cooperation / work with special services of the former regime.

However, according to other scientists, lustration means not only the screening of candidates for the relevant management public positions, but also the purification by their own compulsion to refuse them from office and punish them with public shame. In the countries of Central and Eastern Europe, and in particular in Ukraine, the implementation of the state policy of power cleaning by lustration has acquired specific content, which was determined by a number of factors (content, conditions and time of implementation).

\section{Analysis of recent research and publications.}

The issues of adherence to the concept of sustainable development in the context of the implementation of the state policy of power cleaning in the context of political transformations in Central and Eastern Europe and Ukraine attracted the 
attention of a wide range of civil society. It was reflected in the various journalistic developments in each country where these processes took place. Experts, journalists, politicians have tried to give their own perspective on these processes, analyzing the experience of other countries and giving them different opinions. The scientific approach to the study of this problem began to be formed in the mid-1990s.

From this time, the political scientists, historians, specialists in public administration, sociologists and lawyers have been trying hard enough to investigate it. Among domestic and foreign scientists who have studied this problem at the scientific level one could call Andrzej Hanko (Andrzej Hanko 2000), Cecylia Kuta (Cecylia Kuta. 2004), Mateusz Pazdej (Mateusz Pazdej. 2015). Michal Krotoszynski (Michal Krotoszynski. 2014), Volodymyr Goshovskyi (Volodymyr Goshovskiy. (2017), Zakharov Ye. Захаров Є. Ю. 2013), Karpova N. (Карпова H. 2020), Ogijenko V. (Огієнко B. 2012), Savchenko O. (Савченко О.В.), Turchyn Ја. (Турчин Ярина. 2015) and others. Here, various aspects of the problem are disclosed. However, the need to analyze the issues outlined in these articles is determined by our own tasks - the search for effective mechanisms of power cleaning through lustration with respect for the rights and freedoms of man and citizen.

In order to study in details the problems of implementing the state policy of power cleaning in different countries and to determine the national specificity of solving these problems in this area of public administration, it is important to analyze international and national legislation. In this regard, the authors analyzed the regulatory documents of the respective countries, including Ukraine, which fixed and regulated the solution of these problems.

\section{Unresolved issues that are part of a common problem.}

It must be acknowledged that the growing interest of the domestic and international community in defining effective mechanisms for power cleaning, in particular through lustration, has now emerged. After all, according to the experience of many countries that have taken this step, the public policy in the system of public administration of each country in this direction was carried out according to its own rules.

It should be considered that the solution to the lustration task is to be ensured by taking into account the wide range of threats that may be involved in ensuring the sustainable development of the state, as well as protecting human rights and respecting the principle of the presumption of innocence. This is actual for every state that has embarked to the implementation of the state policy of power cleaning on the path of transformational change.

In scientific research, lustration topics are more often revealed in the context of case-bycase analysis. However, it is the analysis of different models of implementation of the state policy of power cleaning by lustration on the experience of different countries, followed by the identification of the positive and negative consequences of their implementation that will help to outline the optimal mechanisms for their implementation in domestic experience.

After all, the chosen path of directing Ukraine to a positive result in the public administration system with observance of the principles of professionalism, professional 
ethics of civil officers and transparency of management requires a prudent state policy in the power cleaning by lustration. Accordingly, this requires a comprehensive scientific substantiation and creation of new approaches to the formation of theoretical and practical foundations of regulation, taking into account the values of the international concept of sustainable development in conditions of democratization of society. Therefore, it is necessary to carry out a systematic analysis of the practices of different countries in the power cleaning through lustration and identify the positive and negative aspects of implementation in each individual country.

It should be noted that today there are no comprehensive scientific developments in this field. Therefore, there is a need to strengthen scientific and applied research in this area. And it is important to consider the implementation of foreign experience in the national system of public administration, even with the positive results of their implementation, because it is necessary to take into account the national cultural characteristics of the country, its own political and legal base.

The goal of the article is to analyze the sphere implementation of the state policy of power cleaning by lustration in the conditions of political transformations on the experience of the countries of Central-Eastern Europe and Ukraine in order to ensure the sustainable development of the state.

\section{Basic material.}

Nowadays an extremely important task for the government is to create conditions for ensuring effective public administration, under which the higher principles of transparency of administration and professionalism will be fulfilled in the performance of their official duties, when the interests of the state will over personal ones.

One of the steps in accomplishing this task can be conducting the effective state policy of power cleaning through lustration.

The term lustration comes from the Latin word lustratio ("cleaning by means of sacrifices"), which in the modern sense means the process of reviewing clerical items.

The concept of lustration has taken on a special meaning after the fall of the communist regime in the countries of Central and Eastern Europe. According to Andrzej Pachkowski, the term "lustration" was first used by Czech Interior Minister Richard Sacher to determine the eligibility of candidates for parliamentary elections in June 1990 if they were undercover officers of the security apparatus (Cecylia Kuta. 2004.P. 99).

For the first time, lustration as a mechanism of purification of power in public policy was applied in the countries of Central and Eastern Europe during the "velvet revolutions". However, in each of the countries where such steps have taken place in the public administration system, these processes have taken their own forms and resulted in own consequences.

Referring to the analysis of the lustration experience of each individual country in Central and Eastern Europe, in each of its models there were different factors (conditions, time, subjects and objects of implementation, subject and scope of lustration practices, etc.) that was reflected on the final results as well. 


\section{Lustration in Poland.}

During the time of the functioning of the one-party system of government in the Polish People's Republic, the maintenance of the totalitarian regime was due to the well-established system of governing through the brutally acting repressive bodies, which were the communist security organs (in particular, the Security Service). Its aim was to combat and dismantle opposition political powers and to create a homogeneous socialist mass that is easy to govern. All this happened through the brutal oppression of citizens' rights and freedoms. Accordingly, Security Service officers (officers, undercover workers) occupied a special position in the social hierarchy and were categorized as privileged. They have got guaranteed security, benefits and inviolability.

However, significant changes in their interpretation have taken place since 1989, after Solidarity's appearance and the fall of the Polish People's Republic. Their actions were found to be incompatible with the rule of law, and the state needed decisive steps to dispose them.

Crucial to this was the period between February 6 and April 5 1989, when the necessary strategic steps in state policy for peaceful transformation in the country were identified in round table discussions between representatives of the Polish People's Republic, the opposition and the Church. One of the important steps towards these transformations was the lustration of those persons involved in the activities of the communist security agencies.

The main purpose of the lustration processes that began in 1989 was to test the ability of people to perform duties in the new political situation. As a result of such a review, cases could be identified that officers who did not receive a positive assessment should have left the service by July 31, 1990.

A more complete lustration project was presented by the Jan Olszewski government in the resolution of May 28, 1992, which imposed "obligation for the Minister of the Interior to provide full information on persons performing certain public functions who were security personnel in 1945-1990" (Michal Krotoszynski. 2014. P.132).

The resolution of 28 May 1992 did not produce any relevant results, since it did not fully comply with the human rights protection system and many lustration conclusions have been challenged. As a result, the implementation of the Resolution was suspended by the decision of the Constitutional Court of Poland of 19 June 1992 due to its illegality. Accordingly, this stage of lustration state policy was characterized by the general absence of an institutionalized model of lustration. That is why at this time no significant lustration was carried out.

The next stage in Poland's lustration state policy was started in 1996, when work on a new lustration law began. For example, on August 23, 1996, an Extraordinary Commission for the Consideration of Draft Laws on Lustration was appointed, and on April 11, 1997, the Law "On Lustration" was adopted (Ustawa z dnia 11 kwietnia 1997 r.).

According to this Lustration Law, the persons to whom the lustration proceedings had to be applied were the President, ministers, deputies, senators, judges and prosecutors, as well as members of the supervisory boards and directors of Polish Television and Polish Radio. In order to verify them, it was necessary to submit the relevant applications, 
which had subsequently to be examined by the lustration court regarding the connection of these higher officials with the security authorities during the communist period.

The Lustration Law also initiated the creation of special institutions which had to assume the function of lustration. As a result, on December 18, 1998, the Seimas decided to establish a National Memory Institute - the Commission on the prosecution of crimes against the Polish Nation. Among other things this institution had to deal with analyzing the security documents and publishing reports and research on recent Polish history

The aforementioned period in the implementation of the state policy of the Republic of Poland on power cleaning by lustration was characterized by the existence of an institutionalized form of lustration, which was based on punishment not for past relations with state security bodies, but for a factual false statements of their existence (Michal Krotoszynski. 2014. P.132).

The next stage in the lustration state policy of the Republic of Poland was the period 2006-2007, which emerged from a new legislative initiative on lustration - the Law of 18 October 2006 on disclosure of documents of the state security authorities in 1944-1990 and the contents of these documents (Mateusz Pazdej. 2015).

The new law was intended to completely change the form of lustration in Poland. However, it did not come into force and, accordingly, did not affect the form of lustration as a model of punishment.

On February 14, 2007 amendments to the Law on Lustation of April 11, 1997 were adopted. Since then, the state policy of purification of power has been implemented in two directions co-existing lustration procedures: 1) verification of lustration declarations; 2) inspection of officials regarding their work in security bodies, which is carried out by entering the data to the appropriate database of the Institute of National Memory.

Thus, characterizing the Polish model of lustration, it should be noted that since 1992, its main steps in public policy have been implemented on a continuous basis with a gradual strengthening of their rules.

Lustration in Poland is currently aimed at checking all incoming civil servants for their involvement to the former communist regime in that country. The functions of such verification are vested in the National Memory Institute's Lustration Office. The appropriate procedure applies from the President and to the Vice-Rector of a higher education institution (Volodymyr Goshovskiy. 2017).

\section{Lustration in the Czech Republic and Slovakia.}

As early as Czechoslovakia, on April 4, 1991, the Law on Lustration was adopted (in the Czech Republic this Law is still in force), according to which from October of the current year all employees of the state administration, police, army and prison, as well as persons who hold senior management positions in public radio and television, in state-owned enterprises and state-owned companies checked for cooperation with the communist security service. The law also forbade access to the above-mentioned institutions for 5 years to STB officers, Czechoslovakian ORMO staff, communist party activists, from the county level (except for the Prague Spring period and persons later repressed by the authorities). 
After the partition of Czechoslovakia (with the formation of separate Czech and Slovak Republics), the newly formed republics adopted most of the legal regulations originated from the federation, including the Law on Lustration. However, the implementation of its rules and the implementation of lustration state policy in each of them went their own way.

In Slovakia, the Lustration Law of 1991 became ineffective in the spring of 1994 after the Slovak Information Service lost the right to issue lustration certificates. At the beginning of 1997, the Law completely lost its force due to the exhaustion of lustration conditions (5 years). This is the case today. The attempts to restore the action of this law to certain democratic political forces has failed.

On the other, there was a lustration state policy in the Czech Republic. As early as March 10, 1992, the Constitutional Court amended the Lustration Law.

The lustration process in the country was further intensified by the adoption on 9 July 1993 of the Law on the Unlawfulness of the Communist Regime, which recognized that the Czechoslovak communist regime was criminal and disenfranchised.

According to the Law, the Communist Party was recognized as a criminal organization with deserving condemnation, as did other organizations based on its ideology. It was alleged here that the activities of these institutions were aimed at depriving people of their rights and suppressing democracy (Ustawa z dnia 11 kwietnia 1997 r.). Accordingly, the Law stated that in the case of political crimes committed by the communist regime, the statute of limitations would be taken into account not from the moment of committing the criminal act, but from the real possibility of criminal proceedings, i.e. from 1990. The Law also establishes the Office for documentation and prosecution of communist crimes (Andrzej Hanko. 2000).

The lustration processes in the Czech Republic were held in a rather intense struggle of different political forces, but with the victory in favor of lustration supporters. Despite strong resistance from the left wing and the veto of President Havel, claiming that lustration in the Czech Republic "was a child of the revolution and as such ceased to be necessary", the right majority of parliament adopted in 1995 a provision to continue the lustration act until the end of 2000 (Andrzej Hanko. 2000). And since 1996, the law has become permanent.

In 2007, a law was adopted in the Czech Republic to establish an Institute for the Study of Totalitarian Regimes and Archives of the Security Service.

Thus, the lustration in the Czech Republic was aimed at minimizing the consequences of the communist regime as much as possible by eliminating those who were involved in it, and proceeded in two ways: 1) informing the society about the crimes of the totalitarian regime by promulgating information on the connection of officials with the services the security of the occupying powers (in particular, about 140,000 names were published who cooperated with the communist regime during 1948-1989); 2) punishing those in power for a five-year ban from holding positions in state authorities.

\section{Hungarian lustration model.}

The next country to introduce state-level lustration measures was Hungary 
The first attempts to initiate lustration processes have taken place since 1990, when a draft law on lustration was initiated in Parliament, raising the issue of declassification of documents related to the activities of the Department III of the Ministry of Internal Affairs, which dealt with the persecution of anti-communist opposition. Politicians and civil servants also collaborated with the security service. The new law provided for a ban on occupying senior positions in the state by employees and co-workers of the communist political secret police. However, this bill was rejected.

A new bill was introduced in May 1991 to expand the objects list of the lustration process. The list already included heads of higher education institutions, media staff, and more. However, this bill was also not adopted (vetoed by the Constitutional Tribunal).

Some changes in state lustration policy occurred in 1992 with the adoption of the ZeteniTakach Law, which provided for the sanction of criminal prosecution for persons recognized as traitors to the Motherland during the communist regime from December 1944 to May 1990. However, in 1994, the Constitutional Court found that such rules of law were unlawful because it saw political persecution as political revenge. The Constitutional Court found that only authorizing the public to open a list of agents if there was a public interest in disclosing their past. And public interest may be justified if a person wishes to occupy a public office.

This was the first stage of lustration (1992-1994).

That same year, in 1994, the Parliament approved and entered into force on 1 July the Law on Lustration, which restricted access to state administrative posts to persons who were related to former special services. Even researchers (rectors, deans, heads of departments of educational establishments), journalists, judges, prosecutors, bank directors and others were subject to lustration. The lustration panel was to be drawn up by a committee consisting of three judges authorized by parliament. The sanction for the refusal to admit to the respective posts was to publish cooperation with the state security authorities during the communist era. Restrictions on holding appropriate positions were imposed for 4 years.

However, political controversy has been pending for some time regarding the officials who are subject to lustration. These issues were raised by the Constitutional Tribunal. In particular, it concerned persons who were not directly assigned to public servants and did not participate in the political and public life of the state. Therefore, the final lustration in Hungary began only in July 1996.

When the term of the restrictions on the employment of certain categories of persons under the Law was exhausted in 2000, it was extended for another four years.

A new phase in Hungary's lustration state policy began in early 2005.

Thus, on January 5, 2005, amendments were made to the Law on Lustration, which prohibited the introduction of new court lustration cases, and all previously initiated cases had to be closed by June 30, 2005. Since then, lustration judges have ceased their activities.

Analyzing Hungary's experience in implementing a lustration state policy, we can conclude that the lustration law was not repressive in the direction of decommunization. It restricted only access to the relevant posts of persons who were related to him. 


\section{Lustration as a measure of opening the archives of special services in Romania and Bulgaria.}

Lustration in Romania and Bulgaria was sufficiently delayed in time. It began only in the second half of the 1990s.

Romania's Lustration Law regulated the opening of the Securitate secret police archives. It should be noted that the aforementioned Law did not bear any repressive effect. It only determined the need to inspect important officials in the state for cooperation with the security service. Even confirming such cooperation did not deprive officials of the right to hold office.

However, even with the loyalty of the sanctions of this Law, the problem of declassification of archival materials was not solved due to still difficult access to them. Only in 2006 the more favorable conditions for implementing the basic principles of lustration state policy in Romania were identified.

A similar model of lustration occurred in Bulgaria. Its purpose was not to purify power from officials of the past, but to disclose archival data on the activities of communist organizations and make them public. And such a law was adopted only in 2006.

\section{Lustration in the Baltic States.}

Among the countries in the post-Soviet space, the first countries that resorted to lustration processes were the Baltic countries - Lithuania, Latvia and Estonia. Here in 1990 in the parliaments of these countries raised the issue of lustration.

However, these processes were somewhat complicated here, as a result of the exit from the Soviet Union and considerable control of the KGB, many archival resources were taken to the Russian Federation.

Compared to other countries where the Lustration Institute was introduced, the laws adopted in the Baltic States were the most restrictive. According to these laws, the soviet KGB officers were not only allowed to participate in parliamentary elections but also to obtain citizenship. All the archives were opened for this purpose (Огієнко B. 2012). Thus, the state policy of power cleaning has become quite radical. For instance, in Estonia and Latvia, the Law on Citizenship (in Latvia - adopted by the Seimas on July 22, 1994) was adopted, according to which "Soviet emigrants" (mainly Russians) who moved to the Baltic republics after July 1940 (at the time of the USSR collapse they made up to $40 \%$ of the population of Latvia, 30\% - in Estonia, 10\% - in Lithuania) were denied automatic citizenship. This required an examination of the national language, history and national anthem of the countries of residence

Thus, in 1992, a law on elections was adopted in Latvia, according to which each candidate for deputy was required to make a written statement about the presence or absence of their contacts with Soviet or other special services. In 1994, the lustration law prohibited running in any election to local or state government bodies of USSR special services officers and full members of the CPSU. According to the Law on the Elections to the Latvian Seim of 1995, persons who were members of the Communist Party after January 13, 1991, as well as the workers and agents of the USSR State Security Committee (KGB of the USSR) were not allowed to vote. 
In Estonia, the basic principles of lustration public policy were implemented in accordance with the following laws. The first is the Oath-of-Law Act of 1992, according to which each of the candidates for a certain state position was obliged while taking an oath to inform that he was not in the service of the security authorities of the occupying States of Estonia (USSR or Germany) or in the intelligence or counterintelligence agencies of their troops, or he wasn't an agent and did not participate in the persecution and repression of the Estonians by political persuasion, disloyalty, class affiliation or service in the government or armed forces of the Republic of Estonia.

The second law that triggered lustration in Estonia was the "On the identification of employees and agents of the special services of the occupying states of Estonia" from 1995. The Nazi Germany and the Soviet Union were recognized as occupying states. According to the Law, all intelligence agencies had to voluntarily report this information to the Estonian Police within a year. No punitive sanctions were imposed on persons who did it voluntarily. If such information was found, they should made it public.

In 1998, a similar law was adopted in Lithuania, which regulated the procedure for identifying employees and agents of special services of the occupying States. It was necessary to check the mandates of the deputies who were suspected of conscious cooperation with the special services of the USSR or other states. The law defined the creation of a special deputy commission of the relevant council, to which officials of the prosecutor's office, internal affairs and national security services were involved, if necessary.

Analyzing the experience of the Baltic States in pursuing a lustration state policy, it should be noted that it was implemented on a rather rigid basis and aimed at ensuring complete decommunization through individual punishment. This was one of the measures to counteract rather active threats from the Russian Federation as a modern aggressor state.

\section{Formalization of lustration mechanisms at the international level}

Summarizing the experience of the countries of Central and Eastern Europe in the process of lustration, it should be noted that ensuring its implementation in the conditions of development of democracy and guaranteeing the rights and freedoms of the individual and the citizen required internationally agreed mechanisms of its regulation. After all, the implementation of lustration as a mechanism of purification of power carries with it certain threats: lustration can become a means of political retribution (revenge), that is, a means of political struggle with opposition forces and their removal from power. Accordingly, this may be an obstacle to democratic development.

Therefore, there is a problem of defining adequate criteria for ensuring the legal value basis for power cleaning from compromised political forces and the bureaucracy.

In order to prevent these negative effects of lustration, the international community, in the context of the functioning of the Council of Europe, has set out the task of formalizing the requirements to it, which should become a signpost for the member states in implementing their basic lustration principles. One of the important documents was Resolution 1096 "On measures to overcome the consequences of past communist 
totalitarian systems", adopted in 1996 by the Parliamentary Assembly of the Council of Europe.

The aforementioned Resolution 1096 was aimed at preventing the violation of human rights by representatives of totalitarian communist regimes, who held positions in the power structures of the defined period and could significantly impede the transformation (Турчин Ярина. (2015)]. This document recommended that countries of transition type get rid of all signs of totalitarianism in the institutional system by: I. Demilitarization; II. Decentralization; III. Demonopolization and privatization; IV. Debureaucratization of society.

Regarding lustration measures, one of the means of decommunization was the "Guiding Principles for Ensuring the Compliance of Lustration Laws and Similar Administrative Measures with the Rule of Law-Based State" [9]. In introducing lustration laws, the Parliamentary Assembly noted that they should not violate the principles of the rule of law and that administrative measures should comply with all legal principles and stand for the protection of human rights. The main purpose of lustration is to protect young democracies, but not to pay off the past.

According to the aforementioned document, the lustration process is proposed to be implemented in accordance with a number of principles, such as: 1) specially created independent commissions, consisting of authoritative citizens, proposed by the President of the state and approved by the legislative body, should be engaged in lustration; 2) lustration may be used solely for the purpose of eliminating or reducing the danger that the object of lustration may cause during the formation and functioning of free democracy; 3) lustration cannot be used for punishment, retribution and revenge; 4) lustration should target those officials who, through their authority, may influence the formulation or implementation of national internal security policies or may be used for human rights violations, such as law enforcement officials, public security and intelligence services, the judiciary and the prosecutor's office ; 5) lustration may not be applied to elective positions, except in cases where the candidate for such a position himself requests to undergo such a procedure; 6) lustration should not be applied to private or semi-private institutions and organizations; 7) the term for which a person loses the right to hold a position should not exceed five years, which is explained by two circumstances: first, the possibility of positive changes in the outlook and habits of the person who has suffered lustration; second, the strengthening of democratic principles in the former communist totalitarian systems; 8) Only those persons who have given orders, committed significant violations of human rights or substantially contributed to such violations shall be removed from their positions; 9) a person may not be lusted solely for contact or cooperation with an organization that was lawful during that relationship, or for personal views or beliefs; 10) lustration of "conscious employees" is only permissible to those who have actually participated, together with government agencies (eg special services) in significant human rights abuses, harmed other persons, and who knew or should have known that their behavior could cause damage; 11) lustration should not be applied to persons under 18 years of age at the time of committing such actions, voluntarily ceasing membership in or cooperating with the organization prior to the start of transition to a democratic regime or acting under duress; 12) lustration may be applied solely to actions, employment or membership of 
organizations that have taken place since 1 January 1980 and until the overthrow of the communist dictatorship; 13) a person may not be lustration without procedural protection (Керівні принципи... 2013).

\section{Lustration in Ukraine:.}

In Ukraine, attempts to launch a lustration mechanism into the state policy of purification of power took place in several stages. For the first time, attempts at lustration of state power took place in the 1990s - at the time of the collapse of the Soviet Union and the acquisition of Independence.

The next stage in the implementation of lustration was the period after the 2004 Orange Revolution. This was manifested in a sufficiently active legislative initiative around the drafting of relevant bills by L. Lukyanenko (2004), O. Tyagnibok (2005), V. Chervoniy (2005), NGO "All-Ukrainian Lustration" (2008), etc.

However, lustration as a mechanism for the power cleaning in Ukraine has become formal and was introduced only in 2014 after the Revolution of Dignity, since the adoption of the Law of Ukraine "On Cleaning of Power" (October 16, 2014) (Про очищення влади. Закон України . 2014).

However, lustration in Ukraine had to take on other features than it did in the countries of Central and Eastern Europe. It was not a power cleaning on the basis of belonging to the past totalitarian (communist) regime. It was already inappropriate to declare lustration against persons involved in the Soviet regime 20 years after the declaration of state independence (this was stated in the Venice Commission Conclusions) (Проміжний висновок щодо закону «про очищення вАади», 2014).

The need for lustration in Ukraine's public administration has arisen because of stagnant crisis processes in the country, leading to bloody mass protests, which resulted in the Revolution of Dignity and, accordingly, a change in power (ex-President V.Yanukovych escape). Accordingly (as confirmed by the Venice Commission in its conclusion), compared to lustration laws in other countries, in Ukraine this law has a wider scope (Проміжний висновок щодо закону «про очищення вАади», 2014).

Accordingly, a new concept of lustration as a mechanism for purifying power was needed. The Law of Ukraine "On Lustration" gave a corresponding definition of lustration of the authorities in Ukraine. It means "a statute or decision of a court prohibiting certain individuals from holding certain positions (in office) (except elected positions) in public authorities and local self-government in order to prevent persons who, by their decisions, actions or inaction carried out measures aimed at usurpation of power by the President of Ukraine V. Yanukovych, undermining the foundations of national security and defense of Ukraine or unlawful violation of human rights and freedoms (Про очищення влади. Закон України. 2014) part one and two of article 1). The conceptual principles of lustration in the Law are the rule of law and lawfulness, openness, transparency and publicity, the presumption of innocence, individual responsibility and guaranteeing the right to protection.

The next step in the initiated state policy on the purification of power was the Law "On restoring confidence to the judiciary in Ukraine", adopted on April 8, 2014, which 
introduced lustration into the judicial system in the form of a judicial review (Про відновлення довіри до судової влади в Україні. 2014).

Immediately after the adoption of the two Laws and, accordingly, the first attempts to put them into action (after the removal of a number of officials from their positions), a debate began on the legitimacy and observance of the principles of protection and guarantees of human and citizen's rights.

In response to this, there has been a reaction from international legal institutions. Thus, a critical assessment of the Law was provided by the Venice Commission in Opinion No. $788 / 2014$ of December 16, 2014. The disadvantages of the Law, noted by the said international institution, include the following provisions: automatic ban to occupy government posts, which is based solely on the fact that a person held a certain position under the previous regime. The prohibition of discrimination against persons on the basis of "occupation of a position at a certain period of time by the relevant board" was found as such a prohibition, which violates the principle of presumption.

The Venice Commission concluded that lustration was not defined by any international binding instrument. But the prohibition of discrimination is defined by the European Convention on Human Rights of 1950 (Article 14 and Protocol 12) and the International Covenant on Civil and Political Rights (Article 26), which, with the consent of the Verkhovna Rada of Ukraine, are part of the national legislation of Ukraine (regulated by Art. .9 of the Constitution of Ukraine).

The Venice Commission's findings also highlighted the lack of clear and obvious grounds for lustration. And this, in turn, can lead to uneven application of the law and political or criminal prosecutions.

The Conclusions also refer to the unlawfulness of the Ministry of Justice of Ukraine to assign lustration functions. And it is so that according to Article 5 of the Law of Ukraine "On Cleaning of Power", the process of lustration in Ukraine (conducting the procedure of inspection of officials) is carried out by the Ministry of Justice of Ukraine [13]. As a result, in November 2014, a Public Council was formed at the Ministry of Justice of Ukraine on lustration, which included 12 members.

The disadvantage of forming a new unit within the Ministry of Justice system is that the Law does not explicitly regulate the activities of the council to ensure public control over the cleaning of power and certain specific powers of the specified body of authority, therefore, the performance of such functions is questionable.

In the following opinion of the Venice Commission No. 788/2014 on June 19, 2015, another violation of the Law on Purification of Power was raised in the anti-corruption content of the Law (Остаточний висновок щодо закону України «Про очищення влади». 2015). It is a rather unjustified combination of anti-corruption and purely lustration measures in one law, since the latter are subject to evaluation through the prism of different international standards. After all, the restriction of access to public office for a period of 10 years by persons who held relevant positions in public authorities during the presidency of Yanukovych could be considered as a radical measure. In the Commission, this raised the question of how this could be met by the principle of proportionality as one of the principles of the process of power cleaning.

The argument for such an assessment of these measures is that the respective sanctions are higher than the sanctions established in the Criminal Code of Ukraine at the time of 
the perpetration of the respective corruption offenses. This underlines the disproportionate nature of anti-corruption measures in relation to general legislation. It is also a violation of the Law that, as a measure of legal responsibility, the relevant sanction in accordance with constitutional requirements and international standards cannot be applied to acts committed prior to the entry into force of the Law of Ukraine "On Purification of Power".

V.Goshovskyi notes that a number of shortcomings should be noted in the analysis of the Lustration Law in Ukraine. (Volodymyr Goshovskiy. 2017) Thus, the absence of clearly defined sanctions for actions committed in the context of carrying out the relevant official powers in the relevant political era, directs its repressive function in relation to positions, but not individual actions. This calls into question the adherence to the principle of individualization of charges and punishments and, accordingly, the principle of the presumption of innocence.

Such a state of affairs is, in fact, a reason for the human rights and citizens rights system to react appropriately to the restoration of citizens' rights through lawsuits both to the courts of different instances of Ukraine and to the European Court of Human Rights, in connection with unlawful dismissals without establishing valid actions and facts.

As it is stated in the article of V. Goshovskyi "Genesis of lustration in the world and its importance for the development of a legal society", the introduction of lustration by the Law of Ukraine "On Cleaning of Power" (October 16, 2014), carries shortcomings both from the legal and political side (Volodymyr Goshovskiy. 2017).

In particular, actions defined under the Law, which are subject to lustration sanctions, are also qualified by the Criminal Code of Ukraine and the Code of Administrative Offenses as sanctioned, respectively, as measures to respond to an offense or a crime. Also, the Code of Laws on Labor of Ukraine and the Law of Ukraine "On Civil Service" provide for the procedure of dismissal from office upon detection of signs of an offense or a crime in actions.

Also, it is quite obvious that conducting lustration measures in order to differentiate itself from the communist past is rather irrelevant, since it does not pose a significant threat to national security because of the passage of time ("the legislation is two decades late") (Volodymyr Goshovskiy. 2017).

It remains erroneous to interpret the Law of Ukraine "On Cleaning of Power" as a measure to combat corruption. After all, in the case of detecting criminal acts in which there are signs of illicit enrichment, criminal or administrative liability should be brought. However, by virtue of the said Law, the punishment is limited only to dismissal, which does not entail criminal or administrative punishment. And because of the imperfection of the Law itself, these forms of punishment can be appealed to the European Court of Human Rights, and criminal prosecution for these acts may be irrelevant just because of the statute of limitations.

Such problematic points of the Law of Ukraine "On Cleaning of Power" apparently have repeatedly been criticized by public opinion and, accordingly, became the subject of consideration of the Constitutional Court of Ukraine and the European Court of Human Rights.

Thus, the decision of the European Court of Human Rights of October 17, 2019 (the Decree has already entered into force) found violations of the rights of Ukrainian 
officials, who were subject to repressive measures, determined by the Law of Ukraine "On Purification of Power". In particular, the Court, in the unanimity of the judges, found a violation of Article 6 (1) (right to a fair court) of the European Convention on Human Rights in connection with the lengthy consideration of the applicants' cases at national level and violation of Article 8 (right to respect for privacy) of the Convention (Карпова Н. 2020).

The European Court of Human Rights also found that the law of cleaning of power applied to an extremely wide range of persons and led to the dismissal of the applicants only on the ground that they had held public office for more than a year during the presidency of Yanukovych or on the basis of holding positions in the Communist Party until 1991. This did not take into account the fact that personal role played in the abuse of power and whether they were personally related to any undemocratic activities that took place during President Yanukovych's reign.

Although the decision was appealed to the European Court of Human Rights, which is being considered by the Grand Chamber, it was not satisfied and has now entered into force.

In view of the above, it is appropriate to note that lustration in Ukraine has acquired a new legal meaning. There was no value point here for cleansing the communist past. However, the identification of new legal bases for the pursuit of a state policy for the cleaning of power has acquired sufficiently unfounded signs, which, accordingly, carried the consequences of incompleteness of this process, political bias and in reality - mass appeals to courts of various instances in Ukraine and the European Court of Human Rights for the purpose restoration of justice and protection of human and citizen's rights.

\section{Conclusions}

Analyzing different models of lustration in the countries of Central and Eastern Europe, we draw attention to the fact that the state policy of power cleaning in each country went its own way and acquired specific content, which was the product of special circumstances (from its conceptual goals and principles to conditions and time). It also remains an actual question to determine the optimal effective mechanisms for cleaning power through lustration. None of the countries that have taken such a political step in the public administration system has gone this route easily. Accordingly, there were claims to the law (both in Poland to the Lustration Resolution of 28 May 1992, which was suspended by the Constitutional Court of Poland), as well as to the response of victims and the public through lawsuits to various courts and the European Court of Human Rights (such as in Ukraine) to restore the rights and freedoms of human and citizen.

Notwithstanding the foregoing, it should be noted that the cleaning of power through lustration, which took place in the 1990s since the "velvet revolutions" in the countries of Central and Eastern Europe (Poland, Czech Republic, Hungary) and the Baltic States (Estonia, Lithuania, Latvia) have had positive effects. Accordingly, there was a clearing of power from the influence of interested pro-communist political forces, which hampered democratic transformations in the states.

In the characterization of the lustration models of each individual mentioned state, it is 
necessary to note a different approach to its implementation: from repressive measures (dismissal from state positions (Czech Republic, Poland) to only informing about the relationship with the security services of communist regimes (Romania, Bulgaria) and conditional repentance .

As for Ukraine, the lustration process, as a means of cleaning power, has only been implemented since 2014. In substance, it was a new model that was aimed not at combating the communist past, but at overthrowing the current political regime of "Yanukovych's times."

The implementation of this step in the state policy of Ukraine did not happen perfectly. The 2014 Law on the Cleaning of Power has been criticized by both international human rights organizations (Venice Commission conclusions) and domestic human rights experts, resulting in numerous lawsuits to courts for the restoration of human and citizen rights.

It is important to note now that, on the path to democratization of society and overcoming the negative consequences of the activity of undemocratic political regimes, lustration as a mechanism of power cleaning is a reasonable political step. However, its implementation requires a prudent approach to defining the principles of legal regulation, the establishment of appropriate institutions to ensure the implementation of lustration and guarantee the protection of human and citizen's rights and freedoms from political persecution.

The prospect of further research may be scientific, theoretical and applied research and development of the investigated problems, the content of which will allow more detailed and broad analysis of the necessity and effectiveness of the implementation of the state policy of power cleaning by lustration. It will systematize and improve the concept of its normalization in national legislation and bring it closer to higher standards of its implementation and will be in line with the higher principles of democracy and sustainable development of society.

\section{References}

Andrzej Hanko. (2000). Rewolucjanie calkiem aksamitna. Gość Niedzielny. 9/2000. 24.02.2000. URL: https://opoka.org.pl/biblioteka/I/IK/czechy_lustracja.html.

Cecylia Kuta. (2004). Lustracja w Polsce na tle krajow Europy Srodkowej / Horyzonty Polityki 2014, Vol.5, № 11. S.97-114. file:///C:/Users/Serg/Downloads/213-Tekst $\% 20$ artyku\%C5\%82u-790-1-1020150524.pdf

Mateusz Pazdej. (2015). Lustracja jako element polskiej transformacji - szkic badawczy /r.2015.6 nr 12 s.99110. URL: file:///C:/Users/Serg/Downloads/8149-8030.pdf

Michal Krotoszynski. (2014) Lustracja w Polsce w swietle modeli sprawiedliwosci okresu tranzycji. Helsinska Fundacja Praw Czlowieka, Warszawa, (2014). 158 s. URL: http://beta.hfhr.pl/wpcontent/uploads/2014/06/Lustracja-w-Polsce-w-s\%CC\%81wietle-modelisprawiedliwos\%CC\%81ci-okresu-tranzycji_Micha\% \% $\% \% 82-$ Krotoszyn $\%$ CC\%81ski.pdf

Ustawa z dnia 11 kwietnia 1997 r. o ujawnieniu pracy lub służby w organach bezpieczeństwa państwa lub współpracy z nimi w latach 1944-1990 osób pełniących funkcje publiczne Dz.U. 1997 nr 70 poz. 443.

URL: http://prawo.sejm.gov.pl/isap.nsf/download.xsp/WDU19970700443/U/D19970443Lj.pdf

Volodymyr Goshovskiy. (2017) The genesis of lustration in the world and its significance for the development of law-based society. // Legea si viata. Lanuarie 2017. - P.33-37. 
Zakharov Ye. Yu. (2013). Zasudz̧hennia zlochyniv komunistychnoho rezhymu SRSR / Kharkivska pravozakbysna hrupa. [Condemnation of the crimes of the USSR communist regime / Kharkiv Human Rights Group]. Kharkiv, Prava liudyny, 320 p. URL: http://history.org.ua/LiberUA/978-617-587-1157/978-617-587-115-7.pdf

Karpova N. (2020). Postanova YeSPL po spravi «Poliakh ta inshi proty Ukrainy»: rekomendatsii shchodo provedennia liustratsii [ECtHR Resolution on the case "Poliakh and Others vs. Ukraine: Recommendations related to Lustration ] // Lex Inform. Yurydychni novyny Ukrainy. URL: https://lexinform.com.ua/yuridychna-praktyka/postanova-yespl-po-spravi-polyah-ta-inshi-protyukrayiny-rekomendatsiyi-shhodo-provedennya-lyustratsiyi/

Zakharov Ye. Yu. (2013). Kerivni pryntsypy dlia zabezpechennia vidpovidnosti zakoniv pro liustratsiiu y podibnykh administratyvnykh zakhodiv vymoham derzhavy, zasnovanoi na verkhovenstvi prava [Guidelines for ensuring compliance of lustration laws and similar administrative measures with the requirements of a state based on the rule of law ] / Zakharov Ye. Yu. Zasudzhennia zlochyniv komunistychnoho rezhymu SRSR / Kharkivska pravozakbysna brupa [Condemnation of the crimes of the USSR communist regime / Kharkiv Human Rights Group] Kharkiv: Prava liudyny, 2013, p. 164-167 URL: http:/ / history.org.ua/LiberUA/978-617-587-115-7/978-617-587-115-7.pdf

Ohiienko V. (2012). Vidnaity svii shliakh [Find your way] Tyzhden. № 11 / 2012

Ostatochnyi vysnovok shchodo zakonu Ukrainy "Pro ochyshchennia vlady» (Zakonu "Pro liustratsiiu»). Skhvaleno Venetsianskoiu komisiieiu na yii 103-mu plenarnomu zasidanni (m. Venetsiia, 19-20 chervnia 2015 roku) [Final conclusion on the Law of Ukraine "On Cleaning of Power" (Law "On Lustration"). Approved by the Venice Commission at its 103rd Plenary Session (Venice, 19-20 June 2015)]. URL: . https://forbiddentoforbid.org.ua/wp-content/uploads/2015/11/Visnovok-Venecianskoikomisii_pereklad.pdf?0684a4

Promizhnyi vysnovok shchodo zakonu «pro ochyshchennia vlady» (zakon «pro liustratsiiu») v Ukraini Skhvalenyi Venetsianskoiu Komisiieiu na yii 101-y Plenarnii sesii (Venetsiia, 12-13 hrudnia 2014 rokeu) [Interim Conclusion on the Law on Cleaning of Power (Law on Lustration) in Ukraine Approved by the Venice Commission at its 101st Plenary Session (Venice, 12-13 December 2014)] URL: https://www.venice.coe.int/webforms/documents/default.aspx?pdffile=CDLAD $\% 282014 \% 29044-u k r$

Pro ochyshchennia vlady. Zakon Ukrainy. [On Cleaning of Power. Law of Ukraine] № 1682-VII vid 16.09.2014 r. Vidomosti Verkhovnoi Rady (VVR), 2014, № 4 URL: https://zakon.rada.gov.ua/laws/show/1682-18/stru2/paran5?lang=en

Pro vidnovlennia doviry do sudovoi vlady v Ukraini. Zakon Ukrainy. [On Restoring the Confidence to Judiciary in Ukraine. Law of Ukraine] № 1188-VII vid 08.04.2014 r. Vidomosti Verkhovnoi Rady Ukrainy 2014 r. Vid 06.06.2014, № 23 URL: https://zakon.rada.gov.ua/laws/card/1188-18

Zakharova, Ye.Iu. (2013) Rezoliutsïa PARIe iz vahyvannia qakhodiv z metoiu vykryttia komunistychnykh totalitarnykh system [PACE Resolution on measures to expose communist totalitarian systems] [Elektronnyi resurs]. dokument 7568 vid 3 chervnia 1996 roku - Zakharova Ye.Iu. Zasudzhennia zlochyniv komunistychnoho rezhymu SRSR / Kharkivska pravozakhysna hrupa. [Condemnation of the crimes of the USSR communist regime / Kharkiv Human Rights Group] Kharkiv, Prava liudyny, 2013, p. 160-164 URL: http://history.org.ua/LiberUA/978-617-587-115-7/978-617-587-1157.pdf

Savchenko, O.V. Liustratsiia [Lustration] Entsyklopediia suchasnoi Ukrainy URL: http://esu.com.ua/search_articles.php?id=59953

Turchyn Yaryna. (2015). Liustratsiia yak zasib demokratyzatsii politychnoi systemy Ukrainy [Lustration as a means of democratization of the political system of Ukraine] / Politychni nauky Vol. 1, No. 1, 2015. C.33-38 URL: http://ena.lp.edu.ua/bitstream/ntb/29698/1/007_033_038.pdf 